\title{
社会の変化に関する脅威が道徳判断に及ぼす影響 一日本人大学生を対象とした検討一
}

\author{
朴ゴウン（名古屋大学大学院情報学研究科, park.goun@f.mbox.nagoya-u.ac.jp）
}

The effect of threats related to social system change on moral judgment: Testing Japanese university students Goun Park (Graduate School of Informatics, Nagoya University, Japan)

\begin{abstract}
Previous studies have shown that uncertainty and threat promote politically conservative choices, and that political ideology is also strongly associated with moral foundations. Based on these findings, by manipulating the levels of uncertainty and threat to the future, the current study tested Japanese undergraduates and examined the effects of perceived uncertainty and threat on cognitive motives and moral foundations. To begin with, participants responded to their political attitudes, which were included as a covariate in the following analysis. Two weeks later, participants were randomly assigned to a threat condition or a control condition. In the threat condition, participants were asked to read a brief article describing changes in social system regarding the immigration of foreign workers, which would be likely to evoke the feelings of uncertainty and threat for Japanese university students. In the control condition, participants were asked to read another brief article on the immigration of foreign workers, which would be unlikely to accompany threat. Participants also responded to questions about their cognitive needs and moral foundations. Results showed that compared to those in the control condition, those in the threat condition judged moral deviance behavior to be more wrong across all moral foundations. However, the threat manipulation did not affect participants' cognitive needs measured by the need for cognitive closure. These findings suggest that threat would play a significant role in individuals' moral judgment on wrongness.
\end{abstract}

\section{Key words}

threat, uncertainty, social change, moral judgment, need for cognitive closure

\section{1. 問題 · 目的}

自分や他人の行為の善悪を判断する基準は、多くの文 化において人々の間で普遍的に共有され内在化されてい ると考えられている。 Haidt \& Joseph（2004）は、欧米 圏のみならず非欧米圈における価值観を考慮することに より、そのような基準として 5 つの道徳基盤を想定し た。本研究は、個人が各道徳基盤によ゙の程度依拠した判 断をするかはその個人の動機づけによって変わりうると いう見方（Van de Vyver, Houston, Abrams \& Vasiljevic, 2005; Tamborini et al., 2017）に基づき、不確実性や脅威に対する 個人の知覚が各道徳基盤を重視する程度によ゙のような影 響を与えるかを検討する。

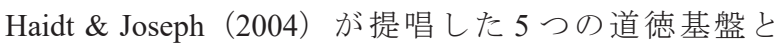
は、他者に害を加えることを避け、思いやることを美徳 とする Harm/Care $(\mathrm{H})$ 、不公平を避け、公正な分配・交 換を美徳とする Fairness（F）、集団を裏切ることを非難 し、忠誠や義務を果たすことを美徳とする Ingroup loyalty (I)、権威に従い、階層的な秩序を遵守することを美徳と する Authority（A）、身体的精神的な污れを忌避し、清潔 や神聖を守ることを美徳とする Purity（P）である。また その後の Haidt らによる研究は、リベラルである個人は H やFといった個人志向を道徳性の基準として強調する一 方、政治的に保守的な個人は個人志向のみならずI、A、 $\mathrm{P}$ といった結束志向を含む 5 つの基盤全てを道徳性の基準
として重視するといったように、道徳基盤と政治イデオ ロギーとの関連性を明らかにしている（Graham, Haidt, \& Nosek, 2009)。

その一方で、これまでの研究は、道徳基準や政治的意 見の選択が認知的・状態的要因によって変わりうること も示している (Lane \& Sulikowski, 2016; Thórisdóttir \& Jost, 2011)。特に不確実性や脅威が高まる状況に置かれた個 人は、自身を守るためにそれに対処しようと動機づけら れる結果、政治的な保守性を反映した選択をしやすくな る (Jost, Fitzsimons, \& Kay, 2004; Morrison, Fast, \& Ybarra, 2009; Craig \& Richeson, 2014)。また、不確実性や劦威の知 覚は、どの道徳基準を強調するかという点にも影響を与 える。例えば、世界がどの程度安全であるのかに対する 懸念には個人差があるが (Altemeyer, 1998)、Van Leeuwen \& Park（2009）は、その懸念を測定するために開発され た Belief in a dangerous world 尺度の得点が高い個人ほど結 束志向を重視しやすく、政治的な保守傾向も強いことを 示している。さらに最近の研究は、不確実性や务威への 対処と関連する認識的な欲求（例えば、認知的完結欲求; Webster \& Kruglanski, 1994）が高い個人ほど結束志向を強 調し、政治的な保守性を示しやすいことを明らかにして いる（Strupp-Levitsky, Noorbaloochi, Shipley, \& Jost, 2020)。 しかし、不確実性や劦威の知覚と道徳判断との関連性を 検討した過去の研究は、もつぱらそれらに関わる心理特 性を尺度で測定し、その得点間の関係を示したものであ る。一方、不確実性や脅威の程度を操作することによっ てそれらが高められると、認識的な欲求や道徳基準にど のような影響が見られるのかについてはあまり検討され 
てきていない。

本研究の目的は、日本人参加者を対象とし、不確実性 や劦威の程度を操作することによって、不確実性や劦威 の知覚による認識的な欲求や道徳基準への影響をより直 接的に検討することであった。また、これまでの研究は、 不確実性や劦威を強く知覚するほど政治的な保守性を反 映した選択をしやすくなること、さらに道徳基準は政治 イデオロギーと強く関連していることを示している。こ れらの知見は、本研究の目的を鑑みると、各人の政治的 イデオロギーを統制した上でのテストが望ましいことを 示唆する。そこで本研究では、事前に各人の政治的イデ オロギーを測定した。そしてその測定から一定期間後に、 各参加者に対して不確実性や劦威の程度を操作し、その 後、認知的完結欲求や道徳基準を測定した。本研究の予 測によれば、不確実性や务威の高い状況にさらされた群 は、そうでない群と比較し、認識的欲求を代表する認知 的完結欲求が高くなり、また道徳基準のうち特に結束志 向を重視するようになるだろう。

\section{2. 方法}

\section{1 参加者}

国立大学の「心理学」を受講する学生 75 名（男性 : 42 名、女性 : 33 名) を対象に質問紙実験を行った。参加者 は、不確実性や务威にさらされる状況である务威あり条 件、または脅威なし条件のどちらかに無作為に配置され た。その結果、为威あり条件は 39 名、劦威なし条件は 36 名であった。

\section{2 手続き}

事前に、参加者は講義内で $3 つ の$ 政治的態度尺度に回 答した。この尺度は、後の分析で道徳判断への政治的態 度の影響を統制することを目的に用いられた。その 3 週 間後、同講義内で参加者は、脅威あり・なし条件のいず れかに分けられ、異なる内容の記事を読んだ。その後、 道徳逸脱行動ストーリーを読み、それそれの行動につい ての道徳判断を行った。最後に認知的完結欲求を測定し た。

\section{3 政治的態度}

具体的には以下の 3 つの異なる尺度を用意して、参加 者の政治的態度を測った。1つ目は、政策への賛成度か ら政治的態度を測定するものであった。参加者は、「国家 安保のためには軍事施設や防衛予算を増やすべきだ」等 の政策 10 項目に対して、自分の国の政策としてどのくら い賛成もしくは反対するのかを 5 件法（1：とても賛成〜 5 ：とても反対）で回答した（以下、「政治的態度 1」と記 す)。2つ目は、キャッチフレーズを用いた政治的態度尺 度（東，1987）であった。参加者は、「愛国心教育」「街頭 デモ」などリベラル・保守どちらかのイデオロギーの価 值と関連する単語（合計 10 単語）に対する印象を 5 件法 （1：とても良い〜 5：とても悪い）で回答した（「政治的 態度 $2 」)$ 。最後は、JES4（日本の有権者を対象にした大規
模調査）での保革イデオロギー尺度であった。参加者は、 自分の政治的立場が保守的あるいは革新的かを 11 件法 $(0$ :

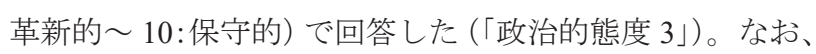
分析においてすべての「政治的態度」得点は、值が大き くなるほど保守的であることを示すように変換し、分析 を行った。

\section{4 脅威の有無の操作}

务威あり条件において参加者は、「政府が外国人労働者 を増やす政策を立てている中、様々な企業が能力のある エリート外国人留学生の採用を年々拡大しており、日本 人大学生の就職活動が難しくなるかもしれない」といっ た社会システムの変化によって生じる妿威を含んだ内容 の記事を読んだ。一方、脅威なし条件において参加者は、 「政府が外国人労働者を増やす政策を立てているが、工 リート外国人留学生の採用には様々な困難があり、展望 としては建設労働者や土木産業労働者を中心とした外国 人労働者採用が主流になる」という内容の記事を読んだ (記事の全文については、付録 1 、付録 2 を参照のこと)。

\section{5 道徳逸脱シナリオ}

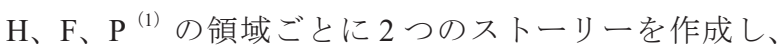
計 6 つの道徳逸脱行動ストーリーを用いた (ストーリー の全文については、付録3を参照のこと)。そして参加者は、 それぞれのストーリーの行動がどの程度間違ったもので あると思うか（1: 全く問題ない〜9: 絶対間違っている）、 およびどの程度悪いものであると思うか（1：全く悪くな い〜 9 : 極めて悪い）の 2 項目を 9 件法で回答した。

具体的なストーリーは以下の通りであった。「大学 2 年 の Cさんは, サークル夏合宿の帰りの運転中に友達がは しゃいでるところに気を取られ，急に飛び出た歩行者に 気づくのが遅れ怪我をさせてしまった。」（H1）、「Kさん は電車に乗るために階段を駆け上り、降りてくる乗客に ぶつかったところ、その乗客が転んで怪我をしてしまっ

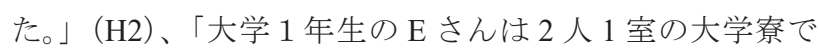
住んでいる。Eさんは食事の時、自分の食材ではなく冷蔵 庫にあるルームメイトの食材を使い勝手に料理をし、お 金を節約した。（F1）、「会社員 Dさんは，会社の印刷室 に用意されている印刷用紙を週に 1 回 1 束ずつ自分用で 家に持ち帰る。」(F2)、「Bさんの家族が飼っていた愛犬が、 自宅の前で車にひかれて死んだ。『犬の肉は美味しい』と 聞いていたこの家族は、こっそりと死骸を切り刻んで料 理し食べてみた。（P1）、「会社員の M さんは週に一回は スーパーで肉のかたまりを買い、それを性行為に使った 後、キレイに洗い料理して食べる。」(P2)。

\section{6 認知的完結欲求尺度}

不確実性や劦威にさらされた個人の認知的完結欲求を 検討するため、Webster \& Kruglanski（1994）の認知的完 結欲求尺度のうち下位項目の Closed-Mindedness に該当す る 6 項目を用いた。調査時間に制約があったため、この ような尺度の一部を用いた。参加者にはその日本語訳を 
示し、5 件法で回答してもらった（1：全く当てはまらな い〜 5 : 非常に当てはまる)。

\section{3. 結果}

\section{1 操作チェック}

社会システムの変化による劦威の操作が劦威の知覚に 影響を与えたかどうかを確認するため、各参加者に対し、 外国人留学生の日本での就職が日本人大学生の雇用に及 ぼす影響について尋ねた。具体的には、「記事を読み、日 本企業の外国人採用拡大政策は、日本人学生にとってど れくらい劦威になると思うか」(項目 1)、「日本企業の外 国人採用拡大政策が自分にどれくらい不利に作用すると 思うか」（項目 2）の 2 項目について尋ね、7 件法で測定 した（1：全く劦威にならない、全く不利ではない〜 7 : とても脅威である、とても不利である)。脅威の知覚に関 する 2 項目間の相関は、 $r(75)=.66, p<.001$ であった。両 項目とも脅威あり条件 (項目 $1: M=5.00, S D=0.21$, 項目 2 : $M=3.84, S D=0.23$ ) の方が劦威なし条件 (項目 $1: M=3.35$, $S D=0.22$, 項目 $2: M=3.11, S D=0.24)$ より劦威をより強 く感じていた (項目 $1: F(1,73)=29.89, p<.001$, 項目 2 : $F(1,73)=4.90, p=.03)$ 。よって脅威の有無はうまく操作 されたと考えられる。

\section{2 認知的完結欲求に対する脅威の影響}

务威を知覚することによって認知的完結欲求が高まる 可能性を検討するため, 务威の有無を独立変数、ClosedMindedness を従属変数、政治的態度 $1 \sim 3$ のそれぞれの 平均值を共変量とした共分散分析を行った。その結果、 脅威の有無の主効果は有意ではなかった（妿威あり：M $=2.24, S D=0.46$, 劦威なし: $M=2.35, S D=0.46, F(1,70)=$ $\left.0.92, p=.34, \eta_{p}^{2}=.01\right)$ 。よって、社会システムの変化から 感じる劦威によって認知的完結欲求が高まることは示さ れなかった。

\section{3 道徳判断に対する脅威の影響}

道徳判断における脅威の有無の影響についても検討し

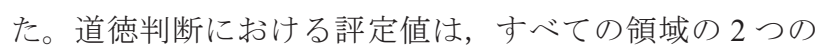
ストーリーの間で高い相関を示した $(r s>.80)$ 。そこで領

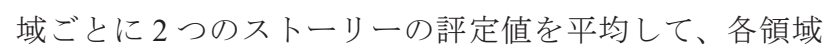
の道徳判断得点を求めた。各条件における平均值は表 1 のとおりである。高い得点ほど非道徳的であるという判 断がなされたことを示す。

各領域の道徳判断得点を従属変数、政治的態度 $1 \sim 3$ のそれぞれの平均值を共変量とした、劦威 (有 $/$ 無; 参加 者間 ) $\times$ 道徳基盤 (purity/care/fairness; 参加者内) の共分 散分析を行った。その結果、脅威の有無の主効果が有意 であった $\left(F(1,70)=7.22, p=.009, \eta_{p}^{2}=.12\right)$ 。劦威を受け た参加者 $(M=14.10, S D=2.74)$ は、脅威を受けなかった 参加者 $(M=13.07, S D=2.84)$ よりも、道徳逸脱行動を非 道徳的なものとして判断していた。一方、脅威の有無と 道徳基盤の交互作用は有意ではなかった $(F(2,140)=1.54$, $\left.p=.22, \eta_{p}^{2}=.02\right)$ 。まとめると、政治的態度を統制した場合、
表 1 : 道徳領域における条件別の道徳判断得点平均

\begin{tabular}{lccc}
\hline & Care & Fairness & Purity \\
\hline Threat & $14.55(2.27)$ & $14.83(1.99)$ & $12.91(3.40)$ \\
Non-Threat & $13.90(2.22)$ & $14.29(2.21)$ & $11.00(2.85)$ \\
\hline
\end{tabular}

注：（）中は $S D$ 、満点は 18 点。

脅威を受けた参加者は、脅威を受けていない参加者より も道徳逸脱行動を非道徳的であると判断し、その傾向に 道徳基盤の領域間の差異はなかった。

\section{4. 考察}

本研究は、不確実性や劦威の程度を操作することによっ て、不確実性や务威の知覚による認識的な欲求や道徳基 準への影響について日本人を対象により直接的に検討し た。その結果、社会システムが変化することによる不確 実性および劦威の程度が高まった個人は、そうでない個 人と比較し、H、F、Pに関する道徳逸脱行動をより悪く、 間違っている行為であると判断した。このことは、社会 システムの変化による艿威が高まると道徳判断に影響を 及ぼすことを示唆する。これまでの先行研究は、脅威お よび不確実性と道徳判断の関連性についてもつぱら個人 の特性に注目して検討していた。この点を踏まえると、 脅威および不確実性を操作した本研究の知見は、過去の 知見を補強し、また脅威および不確実性による影響をよ り明確に示したものであると言えよう。

その一方で、本研究による不確実性や脅威の操作によ る影響は道徳判断にのみ限られ、認知的完結欲求に関し てはその操作による効果が生じなかった。このことは、 認知的完結欲求が個人特性として安定しているものであ り、状況要因による影響を受けにくいことを示唆するか もしれない。しかし本研究では、実施上の時間の制約に より認知的完結欲求尺度の一部しか測定できておらず、 その点、注意が必要である。

加えて興味深いことに、本研究では脅威と道徳基盤の 交互作用が有意には生じず、不確実性や务威の操作によ る道徳判断への影響は道徳領域間で差異がないことが示 唆された。過去の先行研究によれば、不確実性や脅威に よる影響は特に結束領域において顕著にみられることが 示唆される。しかし本研究では、不確実性や劦威の知覚 を高めるために外国人留学生の受け入れといった一種の 集団間葛藤に関連した状況を用いたために、集団に関連 した結束領域について検討することができなかった。そ のため、結束領域は P のみが含まれ、たまたま $\mathrm{P}$ が $\mathrm{H}$ や $\mathrm{F}$ と差異がなかったのか、それとも結束領域全般の示唆す るのか、残念ながら本研究はこの点を区別することがで きない。このことは、本研究は先行研究で示唆された点 を十分に検討できるようなデザインになっておらず、こ の問題点が道徳領域による調整効果を弱めた理由として 考えられる。本研究の知見を確かめるためにも、集団間 葛藤によらない形での不確実性や劦威の操作を実施し、5 つの道徳領域すべてに対して検討するような追実験が今 
後必要である。

これまで述べたように、本研究の限界として、認知的 完結欲求尺度や道徳領域の一部しか検討できていない点 が挙げられる。これに加え、本研究は不確実性や脅威を 操作することによりその影響を直接的に検討したが、喚 起された不確実性や务威がどのような機序で道徳判断に 影響を与えるのか、その点についても調べることができ ていない。今後の研究では、そのプロセスについて検討 していく必要があるだろう。本研究では、不確実性や劦 威による認知的完結欲求への影響を検討したが、その結 果は、認知的完結欲求がそのような状況的な要因による 操作を受けにくいものであることを示唆した。この点を 踏まえると、認知的完結欲求には個人特性としての特徴 があり、むしろそれは喚起された不確実性や脅威に対し てどのように敏感に反応するのかの個人差要因として関 わってくるかもしれない。そのような場合には、不確実 性や劦威による道徳判断への影響を調整するものとして 認知的完結欲求が寄与するかもしれない。また不確実性 や务威に対する敏感さの個人差にかかわる同様の調整変 数として、認知的な側面に着目した場合には、認知欲求 や分析的思考、感情的な側面に着目した場合には共感等 の関連も考えられよう。このような個人差変数に着目す ることは、「個人が各道徳基盤にどの程度依拠した判断を するかはその個人の動機づけによって変わりうるという 見方（Van de Vyver et al., 2005; Tamborini et al., 2017）」の妥 当性を検討寸るためにも有益である。最後に、本研究で は日本人大学生を対象にした検討を行っており、参加者 特性の影響から今回の知見を一般化することは容易では ないという限界も存在する。肙威の操作や道徳逸脱行為 のシナリオに対する反応がどのくらい普遍的なものであ るかを検討するため、今後の研究では調查対象者を特定 年齢および文化に絞らず、幅広く設定する必要があるだ ろう。

まとめると、本研究は、道徳判断に対し喚起された不 確実性や劦威が影響を与えることを実証的に示した。し かし、認知的完結欲求や道徳領域が一部しか検討されて いないため、その知見は限定的である。ただしそのよう な問題点は、不確実性や务威による道徳判断への影響を 調整するものとして個人差变数に着目することによって 不確実性や务威による道徳判断への影響の機序を明らか にできる可能性をむしろ提起するものである。このよう な本研究の示唆は意義深いと言える。具体的には、認知 的完結欲求、認知欲求、分析的思考、共感等による不確 実性や劦威に対する敏感さの個人差とそれによる道徳判 断への影響を調べていくことが今後の研究では期待され る。

\section{謝辞}

本研究に際し、研究の指導を下さった村田光二先生お よび、石井敬子先生、唐沢穣先生に深謝申し上げます。
注

(1) 务威の有無に関わらず、「外国人留学生の受け入れ」と いう前提は、外集団による内集団への進出を意味し、 どの条件も共同体への危機と感じさせる恐れがある。 そのため、結束志向のうち共同体の問題と直接関わる Ingroup および Authority 領域での道徳判断は、特に驾 威を与えない場合でも脅威への対処欲求を高める可能 性があるため、本研究では除外した。

\section{引用文献}

Altemeyer, B. (1998). The other "authoritarian personality." In M. P. Zanna (Ed.), Advances in Experimental Social Psychology, 30 (pp. 47-92). San Diego: Academic Press.

Craig, M. A. \& Richeson, J. A. (2014). More diverse yet less tolerant? How the increasingly diverse racial landscape affects White Americans' racial attitudes. Personality and Social Psychology Bulletin, 25, 1189-1197.

Graham, J., Haidt, J., \& Nosek, B. (2009). The moral foundations of liberals and conservatives. Journal of Personality and Social Psychology, 96, 1029-1046.

Haidt, J. \& Joseph, C. (2004). Intuitive ethics: How innately prepared intuitions generate culturally variable virtues. Daedalus: Special Issue on Human Nature, 133, 55-66.

東正訓（1994）。キャッチフレーズ形式を用いた新しい政 治的態度尺度の構成. 追手門学院大学文学部紀要, 30 , $1-11$.

Jost, J. T., Fitzsimons, G., \& Kay, A. C. (2004). The ideological animal: A system justification view. In J. Greenberg, S. L. Koole, \& T. Pyszczynski (Eds.), Handbook of experimental existential psychology (pp. 263-283). New York: Guilford.

Lane, D. \& Sulikowski, D. (2017). Bleeding-heart conservatives and hard-headed liberals: The dual processes of moral judgements. Personality and Individual Differences, 115, 30-34.

Morrison, K. R., Fast, N. J., \& Ybarra, O. (2009). Group status, perceptions of threat, and support for social inequality. Journal of Experimental Social Psychology, 45, 204-210.

Strupp-Levitsky, M., Noorbaloochi, S., Shipley, A., \& Jost, J. T. (2020). Moral "foundations" as the product of motivated social cognition: Empathy and other psychological underpinnings of ideological divergence in "individualizing" and “binding” concerns. PLoS ONE, 15, e0241144.

Tamborini, R., Hofer, M., Prabhu, S., Grall, C., Novotny, E. R., Hahn, L., \& Klebig, B. (2017). The impact of terrorist attack news on moral intuitions and outgroup prejudice. Mass Communication and Society, 20, 800-824.

Thorisdottir, H. \& Jost, J. T. (2011). Motivated closed-mindedness mediates the effect of threat on political conservatism. Political Psychology, 32, 785-811.

Van Leeuwen, F. \& Park, J. H. (2009). Perceptions of social dangers, moral foundations, and political orientation. Personality and Individual Differences, 47, 169-173.

Van de Vyver, J., Houston, D. M., Abrams, D., \& Vasiljevic, M. 
(2016). Boosting belligerence: How the July 7, 2005, London bombings affected liberals' moral foundations and prejudice. Psychological Science, 27, 169-177.

Webster, D. \& Kruglanski, A. W. (1994). Individual differences in need for cognitive closure. Journal of Personality and Social Psychology, 67, 1049-1062.

\section{付録 1}

「地位への务威なし条件」

Q1. 次の記事を読み、外国人留学生の日本就職が日本人 大学生の雇用にどれくらいの影響を及ぼすと思うかにつ いて答えてください。

「増える留学生の日本就職, 日本人学生の雇用を劦かすのか」

政府は 2020 年の東京オリンピック開催に伴い、人手不足を 解消するため建設労働者を中心に外国人の受け入れ拡大を進 めています。

産業競争力会議では、建設労働者だけではなく、特定分野 の専門家や留学生などいわゆるエリート層の受け入れに関す る議論も行われているようです。外国人の受け入れ拡大によ る今後の労働人口はどのように変化するのでしょうか。また、 日本人大学生の就職活動において能力のある外国人エリート 採用は不利に作用するでしょうか。

厚生労働省の資料によると、いわゆるエリートである外国 人留学生が日本企業に就職した数は、2012 年で 1 万 969 人と なり前年より 2383 人増加し (入国管理局資料)、留学生の日 本就職もここ10 年では増加傾向です。

しかし、実際留学生の就職者数は増えていると言いつつも、 現状は 1 万人程度であり、全体に影響を及ぼす規模にはなっ ていません（※2013 年春の日本人の大卒就職者数は約 37 万 6,000 人)。

今後、さまざまな職種で外国人採用が増えていくものと見 込まれますが、それでも、いわゆるエリート職での留学生の 就職希望と実態では乘離があります。日本学生支援機構の調 査によると、50\%超の留学生が日本企業への就職を希望して いますが、実際に就職できているのは留学生全体の 1 割にも 満たない状況です。

外国人留学生は基本的に日本人と同じ採用試験を受けてい ますし、日本語の壁もあるようです。企業側からは外国人採 用から生じるビザや保険問題など厄介な問題を抱えたくない との声も存在します。このような状況から考えると、外国人 エリートが日本企業に就職し、昇進するということはそう簡 単には行われないようです。産業競争力会議ではいわゆるエ リート層の受け入れに関する議論が行われているようですが、 今後の展望としては政府政策通り建設労働者や土木産業労働 者を中心とした外国人労働者採用が主流となり、外国人受け 入れがいわゆるエリート職にまでは至らないと考えられます。

Q1-1.この記事を読み、日本企業の外国人採用拡大政策は、 日本人学生にとってどれくらい脅威になると思いますか。

全く劦威にならない 1-2-3-4-5-6-7 とても劦威である

Q1-2. 日本企業の外国人採用拡大政策が自分にどれくらい 不利に作用すると思いますか。

全く不利ではない 1-2-3-4-5-6-7 とても不利である

\section{付録 2}

「地位への脅威あり条件」

$\mathrm{Q} 1$. 次の記事を読み、外国人留学生の日本就職が日本人 大学生の雇用にどれくらいの影響を及ぼすと思うかにつ いて答えてください。

「増える留学生の日本就職, 日本人学生の雇用を脅かすのか」

政府は 2020 年の東京オリンピック開催に伴い、人手不足を 解消寸るため建設労働者を中心に外国人の受け入れ拡大を進 めています。

産業競争力会議では、建設労働者だけではなく、特定分野 の専門家や留学生などいわゆるエリート層の受け入れに関寸 る議論も行われているようです。実際、パナソニックやユニ クロ、ローソンなど、能力のある外国人エリートの採用を増 やす日本企業は年々増えています。また、日本人大学生の就 職活動において能力のある外国人エリート採用は不利に作用 するでしょうか。

厚生労働省の資料によると、外国人留学生が日本企業に就 職した数は、 2012 年で 1 万 969 人となり前年より 2383 人増 加し (入国管理局資料)、留学生の日本就職もここ 10 年では 増加傾向です。

また現在、大学や高専など日本の高等教育機関に在籍して いる留学生の数は約 13 万 8,000 人ですが、国は 2020 年をめ どに留学生 30 万人の受け入れを目指しています。

最近は、企業の海外展開の有無に関わらず、純粋に能力の ある人材を確保するために留学生を採用する、というパター ンが増えてきています。日本人学生の応募が多くない職種だ と、能力の高い順に採ったら留学生ばかりだった、という例 も増えているようです。また、以前から外国人留学生採用を 実施していた大手企業の中では大卒の外国人留学生が企業の 役員になっている場合も少なくないです。このように企業側 は、能力さえあれば外国人留学生も日本企業の役員やトップ になれるという方針で昇進にも国籍の壁を崩すつもりだそう です。

一般的に、外国人留学生は、語学力があるし、バイタリティー に富む傾向があり多様性を経営に生かすことができれば、ア ドバンテージは大きいです。

このように経済・社会のグローバル化が進む中、多くの企 業が能力のある外国の人材確保に積極的に取り組むなど、留 学生を採用する企業が増えていることが日本人学生の就職を 肙かしうるという指摘も存在します。

Q1-1.この記事を読み、日本企業の外国人採用拡大政策は、 日本人学生にとってどれくらい劦威になると思いますか。 全く务威にならない 1-2-3-4-5-6-7 とても脅威である

Q1-2. 日本企業の外国人採用拡大政策が自分にどれくらい 不利に作用すると思いますか。

全く不利ではない 1-2-3-4-5-6-7 とても不利である

\section{付録 3}

「道徳逸脱行動ストーリー」

Q2. ここでは, 以下に呈示されるストーリーを読み、各 ストーリーに登場する人物が行った行為がどれくらい間 違っているかもしくは悪いと思うか判断してもらいます。 あなたの気持ちにもつとも近いところに○をつけてくだ さい。 
1. B さんの家族が飼っていた愛犬が、自宅の前で車にひかれ て死んだ。「犬の肉は美味しい」と聞いていたこの家族は、こっ そりと死骸を切り刻んで料理し食べてみた。

・ B さんの家族行動は問題ないですか、それとも間違って いますか?

全く問題ない $1-2-3-4-5-6-7-8-9$ 絶対間違っている

・ Bさんの家族行動はどれくらい悪いことであると思いま すか?

全く悪くない $1-2-3-4-5-6-7-8-9$ 極めて悪い

2. 大学 2 年の $\mathrm{C}$ さんは、サークル夏合宿の帰りの運転中に友 達がはしやいでるところに気を取られ、急に飛び出た歩行者 に気づくのが遅れ怪我をさせてしまった。

・Cさんの行動は問題ないですか、それとも間違っていま すか?

全く問題ない $1-2-3-4-5-6-7-8-9$ 絶対間違っている

・Cさんの行動はどれくらい悪いことであると思います か?

全く悪くない $1-2-3-4-5-6-7-8-9$ 極めて悪い

3. 都内で働いてる 30 代会社員 Dさんは、会社の印刷室に用 意されている印刷用紙を週に 1 回 1 束ずつ自分用で家に持ち 帰る。

・Dさんの行動は問題ないですか、それとも間違ってい ますか?

全く問題ない $1-2-3-4-5-6-7-8-9$ 絶対間違っている

・Dさんの行動はどれくらい悪いことであると思います か?

全く悪くない $1-2-3-4-5-6-7-8-9$ 極めて悪い

4. 大学 1 年生の $\mathrm{E}$ さんは 2 人 1 室の大学寮で住んでいる。 $\mathrm{E}$ さんは食事のとき、自分の食材ではなく冷蔵庫にあるルーム メイトの食材を使い勝手に料理をし、お金を節約した。

・ Eさんの行動は問題ないですか、それとも間違っていま すか?

全く問題ない $1-2-3-4-5-6-7-8-9$ 絶対間違っている

・Eさんの行動はどれくらい悪いことであると思います か?

全く悪くない $1-2-3-4-5-6-7-8-9$ 極めて悪い

5. 高校生の $\mathrm{K} さ ん は$ 電車に乗るために全力で階段を駆け上り、 降りてくる乗客にぶつかったところ、その乗客が転んで怪我 をしてしまった。

・ Kさんの行動は問題ないですか、それとも間違ってい
ますか?

全く問題ない 1-2-3-4-5-6-7-8-9 絶対間違っている

・Kさんの行動はどれくらい悪いことであると思います か?

全く悪くない $1-2-3-4-5-6-7-8-9$ 極めて亜い

6. 会社員の Mさんは週に一回はスーパーで肉のかたまりを買 い、それを性行為に使った後、キレイに洗い料理して食べる。

・ $\mathrm{M}$ さんの行動は問題ないですか、それとも間違ってい ますか?

全く問題ない $1-2-3-4-5-6-7-8-9$ 絶対間違っている

・M さんの行動はどれくらい悪いことであると思います か?

全く悪くない $1-2-3-4-5-6-7-8-9$ 極めて悪い

(受稿 : 2021 年 11 月 30 日 受理 : 2021 年 12 月 17 日) 